\title{
Enteric-Coated TRPM8 Agonist D-3263 Hydrochloride
}

National Cancer Institute

\section{Source}

National Cancer Institute. Enteric-Coated TRPM8 Agonist D-3263 Hydrochloride. NCI

Thesaurus. Code C82660.

An enteric-coated orally bioavailable formulation of the hydrochloride salt of a smallmolecule agonist for transient receptor potential melastatin member 8 (TRPM8 or Trpp8) with potential antineoplastic activity. The active ing redient in enteric-coated TRPM8 agonist D-3263 hydrochloride binds to and activates TRPM8, which may result in an increase in calcium and sodium entry; the disruption of calcium and sodium homeostasis; and the induction of cell death in TRPM8-expressing tumor cells. This agent may decrease dihydrotestosterone (DHT) levels, which may contribute to its inhibitory effects on prostate cancer and BPH. TRPM8 is a transmembrane calcium channel protein that is normally expressed in prostate cells and appears to be overexpressed in benign prostatic hyperplasia (BPH) and in prostate cancer. 